\title{
IbM - PELATIHAN TEKNIK PENGELASAN BAGI MASYARAKAT KURANG PRODUKTIF DI SEKITAR KAMPUS UNIVERSITAS TEUKU UMAR MEULABOH
}

\author{
Maidi Saputra' ${ }^{1)}$ dan Muhammad Ikhsan ${ }^{2)}$ \\ ${ }^{1)}$ Program Studi Teknik Mesin, Universitas Teuku Umar, Alue Peunyareung, Aceh \\ ${ }^{2)}$ Program Studi Teknik Sipil, Universitas Teuku Umar, Alue Peunyareung, Aceh \\ e-mail: maidisaputra@utu.ac.id
}

\begin{abstract}
Problems is faced by partners which is that limited skills, limited financial problems and limited support by various parties, such as government, private and universities. The team devotion from Teuku Umar University of Meulaboh made an activity to solve partner problems with giving some approach method that is giving and training of welding technique and managerial of business and opening of welding workshop. The location of partners is about $1 \mathrm{~km}$ from the Teuku Umar University campus in Ujong Tanoh Darat Village, Meureubo Sub-district, West Aceh District. The determination location of the welding workshop and the determination partners is based on the results of the deliberation UTU service team with the village apparatus, such as the Village Head, Dusun Head, and other village apparatuses. Time of implementation activities is carried out within 10 months with stages are the stages of literature study, site survey activities, feasibility study group of beneficiaries, training and opening of welding workshop, and monitoring and evaluation of welding workshop. The result of giving material about welding technique and managerial welding workshop give good input for the participant, so that the participants become understand and have motivation in running the workshop business. Direct welding technique training provides a good understanding for the participants and provides an example of direct welding techniques on job objects. Welding workshop provides new jobs for less productive people around Teuku Umar University and increase income for the beneficiaries.
\end{abstract}

Keywords : Ujong Tanoh Darat Village, Teuku Umar University Service, Welding Technique, Managerial effort, Welding workshop business.

\section{PENDAHULUAN}

Analisis Situasi

Gampong Ujong Tanoh Darat merupakan salah satu gampong yang terletak di Kecamatan Meureubo, Kabupaten Aceh Barat yang mempunyai jarak sekitar $3 \mathrm{~km}$ dari pusat kecamatan dan sekitar 5 km dari pusat kabupaten Aceh Barat [1].

Gampong Ujong Tanoh Darat yang terletak di Kecamatan Meureubo juga menjadi lokasi berdirinya Universitas Teuku Umar Meulaboh. Jarak antara desa Ujong Tanoh Darat dan Universitas Teuku Umar sekitar $1 \mathrm{~km}$.

Kondisi masyarakat di desa Ujong Tanoh Darat terdiri dari masyarakat kelompok petani sawah maupun kelompok masyarakat yang bergerak dalam usaha perkebunan. Kemudian kondisi pemuda di desa tersebut banyak yang putus sekolah setelah menamatkan jenjang sekolah menengah pertama maupun sekolah jenjang menengah atas. Kelompok pemuda-pemuda tersebut lebih terlihat aktif di warung-warung kopi walaupun sebagian ada yang berkerja membantu orang tua dan usahausaha kecil lainnya [2].

\section{Permasalahan mitra}

Berdasarkan hasil pengamatan dan wawancara dilapangan, maka didapatkan permasalahan yang dihadapi mitra, diantaranya yaitu:

1. Tingkat pendidikan yang relatif rendah sehingga membatasi keahlian yang dikuasai oleh mitra yang akhirnya menghambat pengembangan diri mitra tersebut dan menjadi kurang produktif.

2. Keterbatasan keuangan oleh mitra yang menghambat mitra untuk bisa membuka usaha, sehingga bisa menjadi produktif dan berkembang.

3. Keterbatasan dukungan dari berbagai pihak, baik pemerintah, swasta maupun perguruan tinggi dalam membina mitra, sehingga mitra menjadi kurang produktif [3]. 


\section{Metode pendekatan yang ditawarkan}

Metode pendekatan yang ditawarkan untuk mengatasi permasalahan yang dihadapi oleh mitra antara lain:

1. Pemberian materi tentang teknik pengelasan dan manajerial usah serta praktek langsung dilapangan terhadap objek pengelasan. Dengan adanya materi dan praktek langsung tersebut diharapkan mitra dapat memahami secara dasar dan keseluruhan terhadap konsep-konsep pengelasan dan aplikasi dilapangan serta penyelesaian berbagai persoalan dalam hal teknik pengelasan.

2. Pembukaan usaha pengelasan oleh mitra yang dibantu oleh tim pengabdian dari Universitas Teuku Umar Meulaboh.

Dengan pembukaan usaha pengelasan tersebut diharapkan mitra dapat mengaplikasikan ilmu yang didapat secara teori sebelumnya serta dapat menjadi mitra yang produktif dan lebih berkembang sehingga bisa bermanfaat bagi masyarakat luas [4-7].

\section{Target dan Luaran} ini adalah:

Target dan luaran utama yang direncanakan dapat terlaksana dengan baik dalam kegiatan

\section{Materi dan pelatihan teknik pengelasan serta manajerial usaha (Metode)}

Kelompok mitra dapat memahami secara teori maupun praktek tentang teknik pengelasan, yang menjadi dasar dalam mengembangkan keahlian tentang pengelasan dan penyelesaian berbagai persoalan pekerjaan dalam bidang pengelasan. Kemudian pelatihan manajerial usaha pengelasan menjadi modal dasar kelompok mitra untuk membuka usaha bengkel pengelasan yang bisa berkembang dan bermanfaat bagi masyarakat.

\section{Pembukaan Usaha Bengkel Pengelasan (Produk)}

Tujuan akhir dari pengabdian yang dilakukan ini adalah memberikan pengembangan diri bagi kelompok mitra dalam hal produktivitasnya. Produktivitas kelompok mitra dapat berkembang dengan adanya pembukaan bengkel pengelasan tersebut, kemudian usaha pengelasan ini merupakan aplikasi terhadap teori-teori yang diberikan sebelumnya, baik teori tentang teknik pengelasan maupun teori tentang manajerial usaha.

\section{METODE PELAKSANAAN}

\section{Rencana Pelaksanaan Kegiatan}

Pelaksanaan kegiatan pelatihan teknik pengelasan menurut rencana dilaksanakan di kampus Universitas Teuku Umar Meulaboh, dan selanjutnya pembukaan usaha jasa pengelasan dilakukan di desa Ujong Tanoh Darat Kec. Meurebo, yang terletak tidak jauh dari kampus Universitas Teuku Umar (desa disekitar kampus).

Jangka waktu pelaksanaan kegiatan direncanakan selama 10 bulan, dengan diagram alir rencana pelaksanaan kegiatan diberikan oleh Gambar 1.

\section{Metode Pelaksanaan Kegiatan \\ Penetapan Lokasi Pelaksanaan Kegiatan}

Penetapan lokasi pelaksanaan kegiatan dilakukan berdasarkan kedekatan lokasi tersebut dengan kampus Universitas Teuku Umar Meulaboh, karena kegiatan ini juga bertujuan untuk memberdayakan kelompok masyarakat produktif yang belum berkerja yang berada disekitar kampus, sehingga masyarakat dapat mengambil manfaat dengan kehadiran kampus yang dekat dengan desa mereka.

Kemudian dasar penetapan lokasi pelaksanaan kegiatan lainnya adalah desa tersebut mempunyai banyak kelompok masyarakat produktif yang belum berkerja, yang terdiri dari remaja- 
remaja yang baru selesai menamatkan Sekolah Menengah Atas, serta banyaknya potensi-potensi kelompok usaha yang memanfaatkan jasa pengelasan, seperti adanya lokasi tambang batu bara yang mempunyai kendaraan-kendaraan besar dan alat-alat berat, serta usaha-usaha masyarakat lainnya.

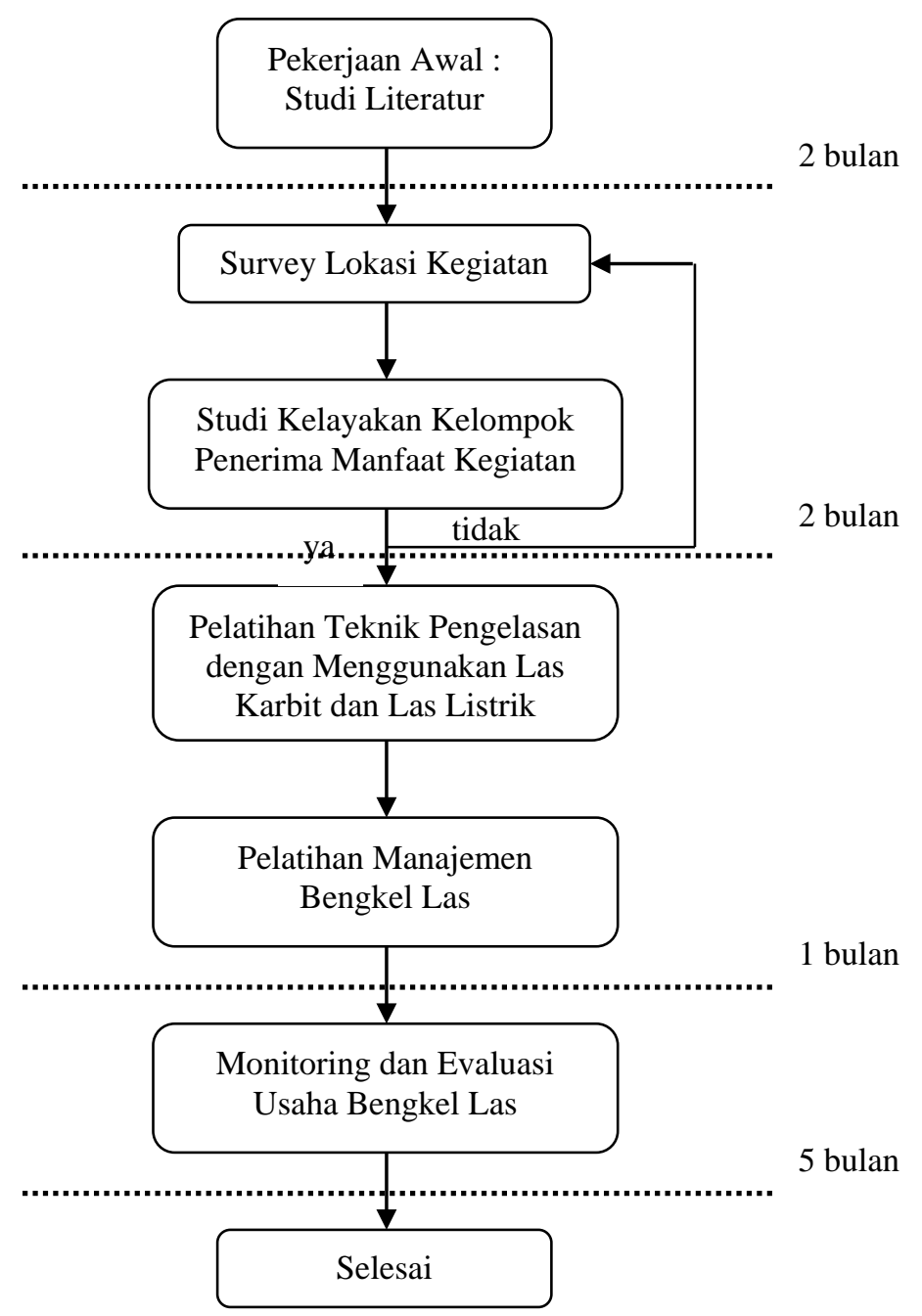

Gambar 1. Diagram alir pelaksanaan kegiatan

\section{Penetapan Peserta Pelatihan}

Penetapan peserta pelatihan didasarkan pada kelompok masyarakat produktif yang belum berkerja di desa Ujong Tanoh Darat. Kelompok masyarakat produktif tersebut terdiri dari remajaremaja yang baru menyelesaikan sekolah menengah atas dan belum berkerja serta mempunyai potensi untuk berkembang dan dapat meningkatkan taraf hidup pribadi maupun keluarganya setelah mengikuti pelatihan teknik pengelasan tersebut.

Pada proses penetapan peserta pelatihan teknik pengelasan ini, saya selaku dosen yang melakukan kegiatan pelatihan berdiskusi serta bermusyawarah dengan pihak aparatur desa, yang terdiri dari pak Keuchik (kepala desa) Ujong Tanoh Darat, Kec. Meurebo dan aparatur desa lainnya.

\section{Pemberian Materi tentang Teknik Pengelasan dan Manajerial Usaha}

Materi teknik pengelasan diberikan kepada mitra sebagai dasar pengetahun tentang teknikteknik pengelasan yang dipakai pada saat proses pengelasan dan menyelesaikan berbagai persoalan yang berkaitan dengan pekerjaan pengelasan. Materi teknik pengelasan merupakan langkah awal yang perlu dipahami oleh mitra sebelum langkah praktek langsung kepada objek yang ingin dikerjakan. 

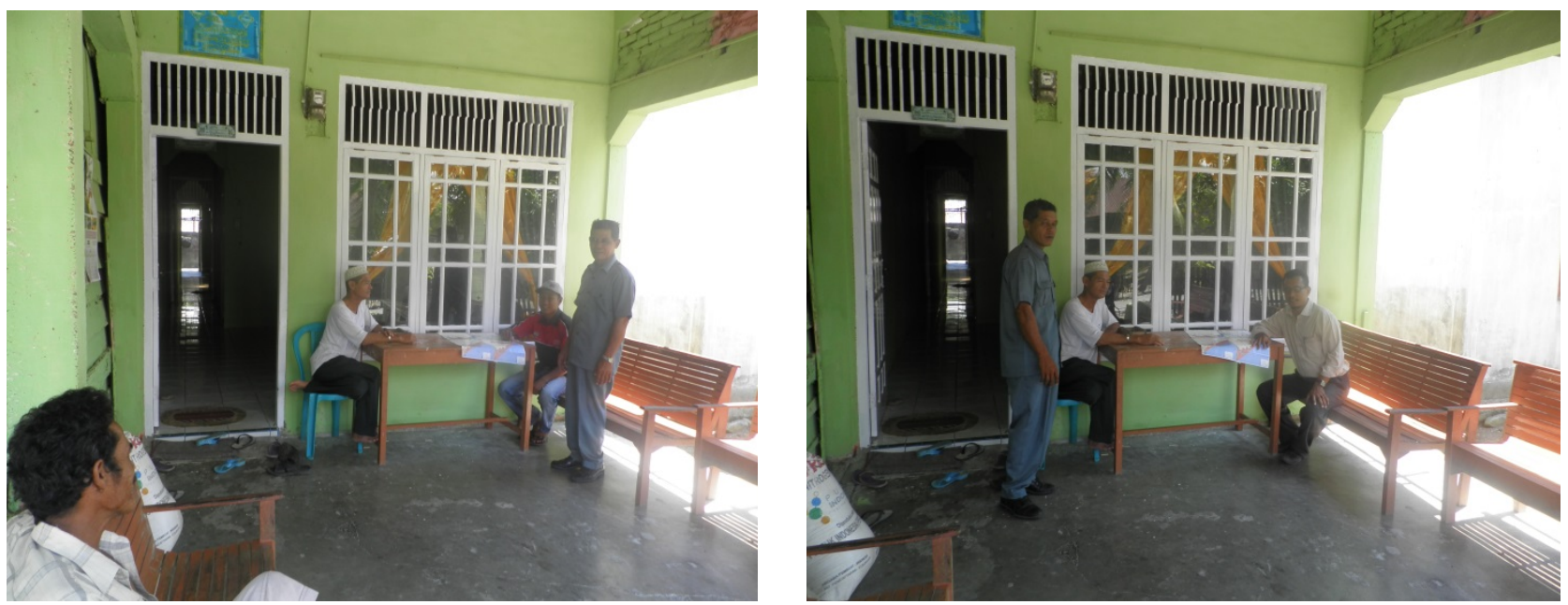

Gambar 2. Diskusi dengan Kepala Desa (Keuchik) tentang pelaksanaan pengabdian

Adapun cakupan materi yang diberikan adalah semua hal yang berhubungan dengan pengelasan dan penyelesaian berbagai persoalan-persoalan dalam pengerjaan pengelasan. Materi teknik pengelasan ini akan diberikan oleh tim dosen pengabdian dari Universitas Teuku Umar Meulaboh dan dibantu oleh beberapa mahasiswa.

Kemudian untuk menunjang usaha bengkel pengelasan, perlu dilakukan pelatihan dan pemberian materi yang berhubungan dengan manajerial usaha. Manajerial usaha mutlak perlu dikuasai dan dipahami oleh pelaku usaha, termasuk bengkel las.

Adapun cakupan materi dari manajerial usaha ini terdiri dari pembuatan model-model pembukuan sederhana dalam mendukung jalannya usaha, sehingga arus keuangan usaha dapat terkontrol dan memberikan hasil yang maksimal. Selain itu perlu kiranya diberikan materi tentang promosi/pemasaran usaha bengkel las, karena dengan adanya ilmu tentang pemasaran maka usaha bengkel pengelasan tersebut dapat lebih berkembang dan bisa memberikan manfaat yang sebesarnya bagi masyarakat.

\section{Pelatihan Teknik Pengelasan dengan Metode Praktek Langsung}

Pelatihan dilaksanakan untuk meningkatkan pengetahuan dan keterampilan mitra dalam proses teknik pengelasan serta menyelesaikan segala macam pekerjaan yang berkaitan dengan pengelasan baik yang bersifat sederhana maupun yang bersifat rumit.

Pelatihan dilakukan dengan metode praktek langsung terhadap objek yang ingin dilakukan pengelasan. Pemilihan objek pengelasan dilakukan dengan berbagai variasi kerumitan dalam mengerjakannya, dengan tujuan mitra dapat lebih memahami dan mendalami teknik-teknik pengelasan yang telah dijelaskan secara teori sebelumnya.

Praktek teknik pengelasan dengan metode langsung terhadap objek ini akan disampaikan oleh tim pengabdian dari Universitas Teuku Umar Meulaboh, dan dibantu oleh mahasiswa serta tim ahli lainnya.

\section{Pembukaan Usaha Bengkel Pengelasan}

Setelah pemberian materi tentang pengelasan dan manajerial usaha, serta pelatihan dengan teknik praktek langsung terhadap objek pengelasan, maka langkah selanjutnya adalah dengan membuka usaha bengkel pengelasan.

Pembukaan usaha bengkel pengelasan ini merupakan tujuan dari pengabdian yang dilakukan. Karena dengan pemberian ilmu yang cukup tentang teori dan praktek pengelasan, maka untuk meningkatkan taraf hidup masyarakat yang kurang produktif dan belum berkembang diperlukan tempat usaha bagi mereka untuk mengembangkan diri dan keluarganya. 
Pembukaan bengkel pengelasan ini berlokasi di Desa Ujong Tanoh Darat, yang merupakan daerah mitra dari pengabdian ini. Adapun jumlah tempat usaha bengkel pengelasan ini adalah 2 unit dengan bantuan monitoring dan evaluasi dari tim pengabdian Universitas Teuku Umar Meulaboh selama 5 bulan.
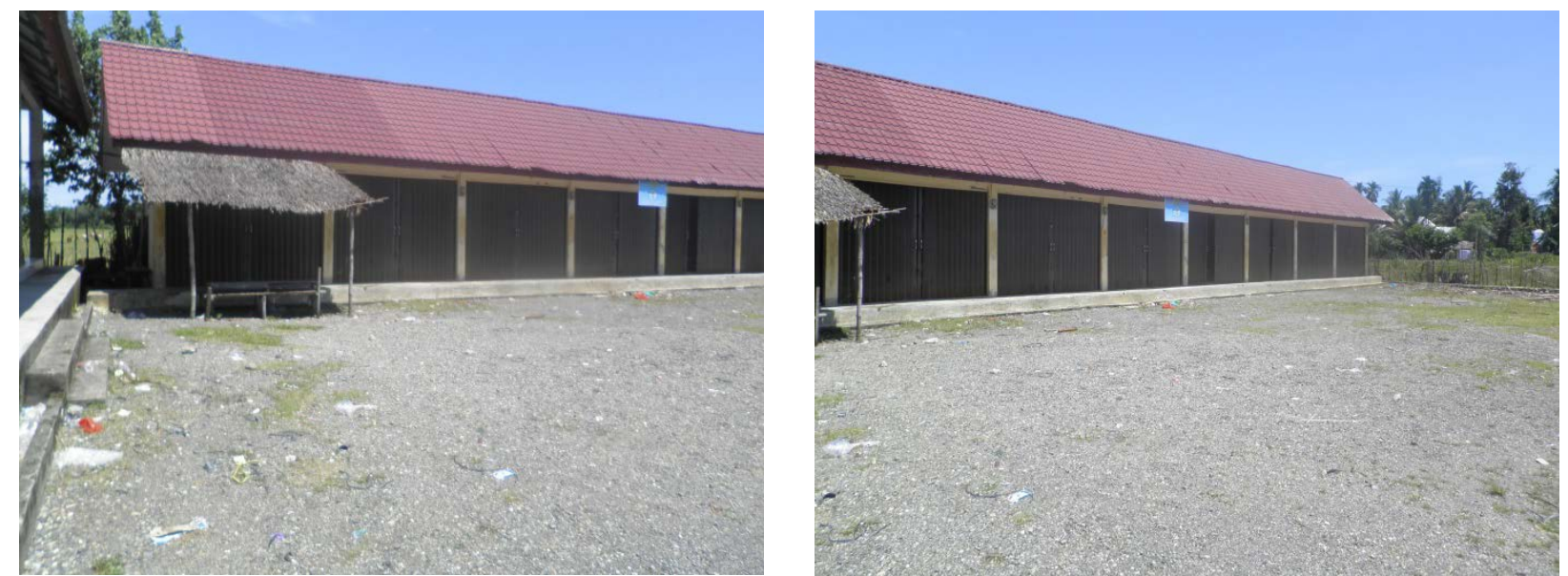

Gambar 3. Lokasi usaha bengkel pengelasan

\section{HASIL DAN PEMBAHASAN}

\section{Pemberian Materi tentang Teknik Pengelasan dan Manajerial Usaha}

Materi yang diberikan kepada peserta pelatihan adalah materi tentang teknik pengelasan yang meliputi pengelasan listrik serta metode-metode pemotongan material. Pemberian materi tentang metode-metode tersebut dilakukan dilokasi perbengkelan yang akan dibuka, pemilihan lokasi tersebut adalah agar proses pemberian materi sesuai dengan konsep usaha perbengkelan yang akan dijalankan/dibuka.
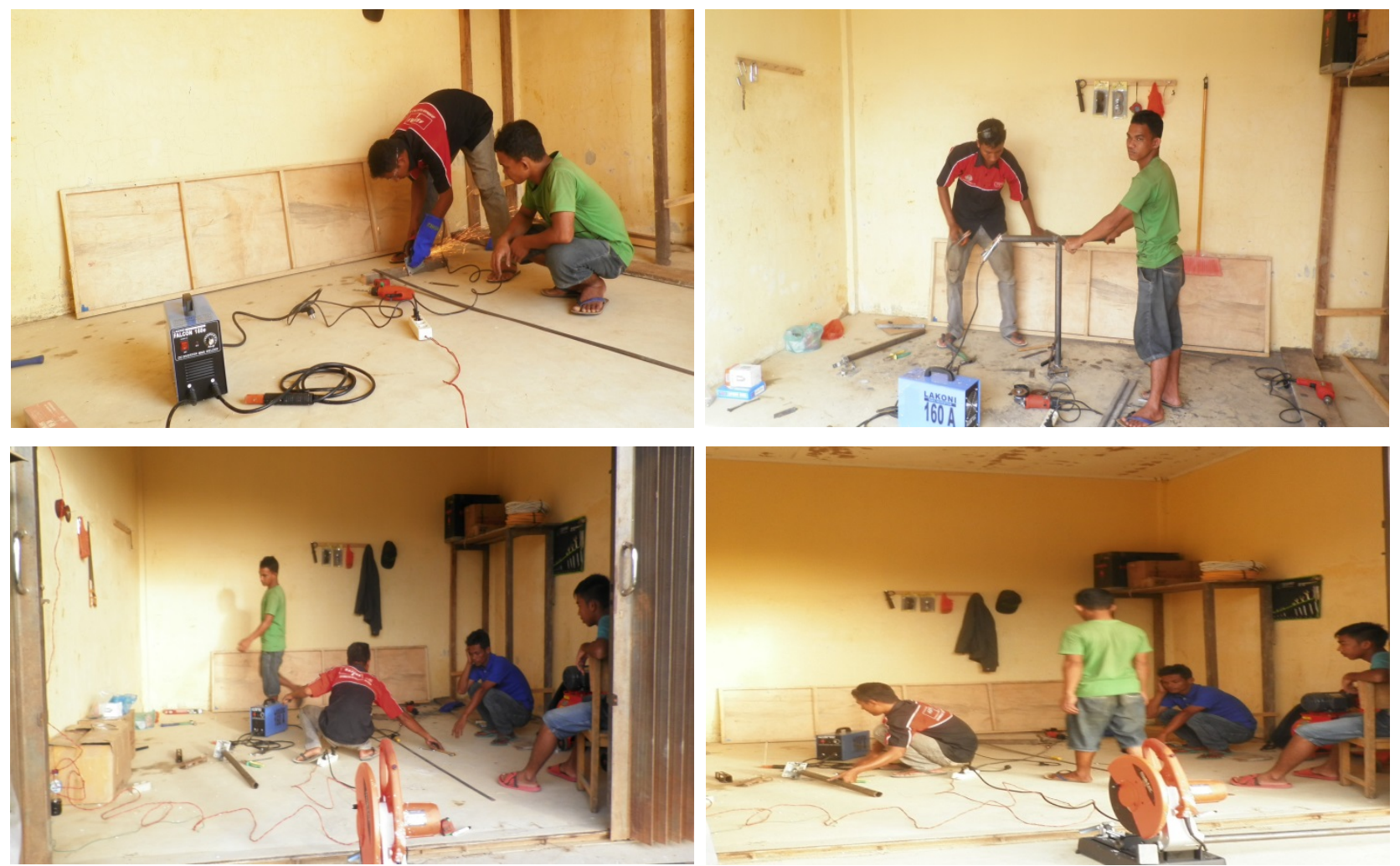

Gambar 4. Pemberian Materi tentang Teknik Pengelasan 
Materi manajerial usaha diberikan oleh dosen yang berpengalaman dalam berbagai bidang usaha, serta mengerti tentang pengembangan dan pemberdayaan usaha sehingga menjadi maju dan jangka panjang [4-7].

\section{Pembukaan Usaha Bengkel Pengelasan}

Pembukaan usaha perbengkelan dilakukan dilokasi desa Ujong Tanoh Darat, Kecamatan Meureubo, Kabupaten Aceh Barat. Usaha perbengkelan ini dibuka setelah dilakukan pemberian materi tentang teknik pengelasan dan manajerial usaha.

Usaha perbengkelan ini dibuka dengan cara penyediaan alat-alat perbengkelan, seperti travo las, mesin gerinda, alat potong gerinda duduk, dsb [4,5,6,7].
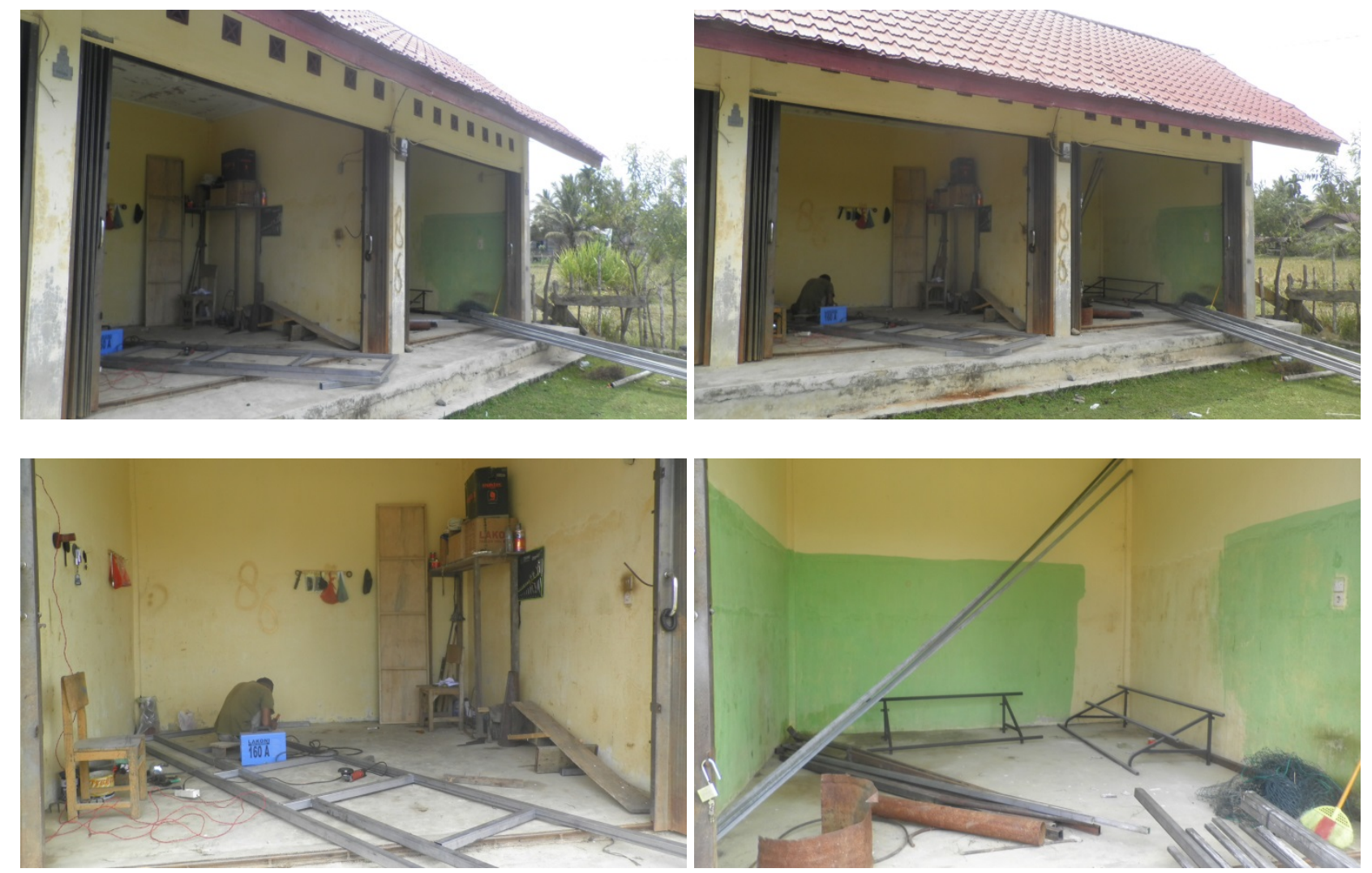

Gambar 5. Pembukaan usaha bengkel pengelasan

\section{SIMPULAN}

Dari data penelitian dan pembahasan, maka dapat disimpulkan sebagai berikut: 1). Hasil dari pemberian materi tentang teknik pengelasan dan manajerial bengkel las memberikan masukan yang baik bagi peserta, sehingga perserta menjadi paham dan mempunyai motivasi dalam menjalankan usaha perbengkelan. 2). Pelatihan teknik pengelasan dengan metode langsung memberikan pemahaman yang baik bagi peserta dan memberikan contoh teknik pengelasan langsung pada objek pekerjaan, dan 3). Usaha bengkel pengelasan memberikan lapangan pekerjaan baru bagi masyarakat kurang produktif disekitar kampus Univ. Teuku Umar dan manambah pendapatan bagi masyarakat penerima manfaat tersebut.

Perlu adanya proses tindak lanjut dari program pengabdian ini, yaitu dalam hal upgrading usaha perbengkelan, baik dari segi alat perbengkelan maupun dari segi manajerial usaha perbengkelan. 


\section{DAFTAR PUSTAKA}

[1]. Pemerintahan Desa Ujong Tanoh Darat, 2014, Profil Desa Ujong Tanoh Darat Kecamatan Meureubo Kabupaten Aceh Barat, Aceh.

[2]. Pemerintahan Desa Ujong Tanoh Darat, 2014, Rencana Pembangunan Jangka Menengah Gampong (RPJMG) Tahun 2014-2018, Aceh.

[3]. Maidi Saputra, 2015, Hasil survey dan wawancara langsung dilokasi desa Ujong Tanoh Darat Kecamatan Meureubo Kabupaten Aceh Barat, Aceh.

[4]. Bram, G. and Dowbs, C., 1975, Manufacturing Technology, London: The Macmillan Press Ltd.

[5]. Harsono Wiryo Sumarto, Toshe Okomura, 1979, Teknologi Pengelasan Logam, Jakarta: Pradnya Paramita.

[6]. Romans, D., Simon, En., 1968, Welding Processes and Technology, London : Pitman.

[7]. Sconmetz, dkk., 1985, Pengerjaan Logam dengan Perkakas Tangan dan Mesin Sederhana, Bandung : Angkasa. 